\title{
Online Reading Strategy in Academic Reading by Foreign Language Learners during Covid 19 Outbreak
}

\author{
Erni Erni 1 \\ DOI: 10.35445/alishlah.v13i1. 481
}

\begin{abstract}
Article Info
Abstract

Keywords: online reading strategy academic reading foreign language learners

This mixed-method research used questionnaires, in-depth interviews, and open-ended questions as the instrument of data collection. Twenty-five samples were selected randomly from 112 populations. The objectives of the study were to explore online reading strategies in academic reading by foreign language learners during the Covid 19 outbreak. This study revealed that: Using online reading strategies by foreign language learners were varied in four different types, namely global strategy, problem-solving strategy, support strategy, and socio-effective strategy. Motivation influenced foreign language learners' online reading strategies for $13.65 \%$ in academic reading during the Covid 19 outbreak; meanwhile, age and gender influenced less. Motivation influenced online reading strategies used by foreign language learners during the Covid 19 outbreak for two purposes: integrated and instrumental motivations. These two types of motivation influenced the choices and use of learners' online reading strategies during the Covid 19 outbreak.
\end{abstract}

Kata kunci: strategi membaca online membaca akademik pelajar bahasa asing

\begin{abstract}
Abstrak
Studi ini menerapkan rancangan peneltitan mixed-method menggunakan kuesioner, wawancara terbuka, dan pertanyaan essay sebagai instrumen pengumpulan data. Dua puluh lima sampel dipilih secara acak dari populasi yang berjumlah 112 mahasiswa program studi pendidikan Bahasa Inggris. Tujuan penelitian adalah untuk mengeksplorasi strategi membaca online, mengetahui pengaruh motivasi terhadap strategi membaca online, mengetahui bagaimana motivasi mempengaruhi strategi membaca online oleh mahasiswa program studi Pendidikan Bahasa Inggris selama wabah Covid 19. Hasil penelitian menunjukkan bahwa strategi membaca online yang diterapkan oleh mahasiwa bervariasi meliputi empat strategi membaca online yaitu strategi global, strategi pemecahan masalah, strategi pendukung, dan strategi efektif-sosial. Motivasi mempengaruhi penggunaan strategi membaca online dalam membaca text akademiksebesar $13.65 \%$ oleh mahasiswa pendidikan Bahasa Inggris selama wabah Covid 19 ,sementara usia, jenis kelamin (gender) memberi pengaruh yang tidak signifikan terhadap penggunaan strategi membaca online. Motivasi memengaruhi strategi membaca online mahasiswa dengan dua tujuan: integrated and instrumental motivation. Kedua jenis motivasi ini mempengaruhi online reading strategies yang digunakan during the Covid 19 outbreak.
\end{abstract}

${ }^{1}$ Universitas Riau, Pekanbaru, Indonesia

Email: erni@lecturer.unri.ac.id 


\section{INTRODUCTION}

Academic reading required critical thinking and academically demanding. It is a purposeful and essential reading of various long literary reading texts designed to complete the study of specific subjects (Sengupta, 2002 in Shen, 2013). Academic reading is complex reading, synthesizing material from several sources through interactive skills. It also requires consciously finding authorial intentions and purposes (Shen, 2013) as reading is not a translation from L2 to L1 only. The reader must decode words or recognize words and access text integration to construct meaning and retain the content of the terms to stimulate their stores of information in their long-term memories (Cunningham \& Stanovich, 1998 in (Sekuler \& Bennett, 2000). Learning reading is a transfer of information or knowledge from writers to readers with any motivation. The learners may transfer knowledge from their second language to their first language or from one course to another through their reading strategies. Transfer information or expertise is influenced by a motivation to transfer, perceptions of opportunity for transfer, and personal beliefs about the transfer (James, 2012). Learners' interest in English cultural products affected their motivated behavior toward the language learned (Kormos \& Csizér, 2008).

During the Covid 19 pandemic, the teaching and learning in Indonesia move from onsite to online learning after the government instructed a Study from Home (SFH) program. This $\mathrm{SFH}$ program aims to scrub the human-to-human spread of coronavirus among students and teachers. Lockdown or new normal were perceived as necessary to limit the spread of the virus as rapid human-to-human transmission occurred. Much about the virus remained unknown (Emma \& Arina Anis, 2020), which also arouse some teaching and learning process problems. This sudden regulation has changed the learning strategy from the onsite to online learning strategy, influenced learners' knowledge and learning strategies. Consequently, information and communication technology has transformed old literacy into new literacy where the lecturers' learning material has also been hypertext.

The hypertext requires students to navigate to sources for reading. To improve learners' ability to read hypertext, teachers need to change their teaching strategies using technology. The research found that metacognitive strategy instruction and ICT development help use various problemsolving, global, and support strategy in online academic reading and improve online reading comprehension (Marboot et al., 2020). His study also highlighted the combination of reading and navigational strategy to examine how students navigate an online environment (Marboot et al., 2020). English language teaching has run online since the government officially declared that Covid 19 was infecting the Indonesian people. There are many platforms available and used by students in accessing reading resources provided by the government, such as Google form or other media. Numerous studies have also indicated the significance of understanding students' performance and behavior using technology in teaching and learning (Alhajri et al., 2017). This new literacy consciously or unconsciously changed the conventional text into hypertext that automatically changed reading strategies into online reading strategy. By online learning, readers applied Global Strategy 23.01\%, Problem-solving strategies 7,18\%, Support strategy 62.32\%, and Socio-affective strategy of 7.49 , which means that technology advances contributed most online reading strategy (Huang et al., 2009). The readers may translate the language they learned by clicking the translation button by online learning reading.

Besides technology advances, motivation also influences foreign language learners' online reading strategies in academic reading during the Covid 19 outbreak. Motivation is a condition of an organism that includes a subjective sense (not necessarily conscious) of desiring some change in self or environment (Lamb et al., 2020). Motivation, learning experience and gender affected learners' learning strategies (Khamkhien, 2010). During the Covid 19 outbreak, researchers studied learning motivation to acknowledge learners' responses to distance learning. Motivation research would have played a key role in identifying the benefits of digital technologies and conceptualizing learners' 
responses to these innovations (Lamb et al., 2020). Motivation is the extent to which individuals work or try to learn a language because of the desire to perform and the satisfaction experienced in these activities (Gardner, 1985). Students' motivation is different in its type and amount (Deci \& Ryan, 1985). Some learners may have Integrative and instrumental motivation to reach their purposes, and some may not. Medium group students show a stronger integrated motivation than instrumental motivation (Teh et al., 2012). The relationship between integrative motivation and instrumental motivation among EFL learners was proved positive and significant (Ghanea et al., 2000).

This research focuses on using online reading strategies in academic reading by foreign language learners during the Covid 19 outbreak. The Covid 19 pandemic has hit the world, which automatically affects the global learning system. Universitas of Riau as a research setting of this study, students have been studying online or study from home since the middle of March 2020. During this $\mathrm{SFH}$, the learning runs through online mode, and the teachers create/use learning platforms, create media and learning material. Language teachers increase the use of the Internet for interaction and provide learners with digital media production and a spirit of interdisciplinarity (Mercer \& Ryan, 2016) to afford learners to increase their digital literacy. The Internet has become the primary means of achieving learning goals, and technology has been changing the students' motivation and reading strategy known as a new literacy. People become highly skilled at using certain technologies to communicate personally, meaningfully, and critically (Chapelle \& Sauro, 2017).

Despite the implementation of SFH suddenly in the school and University, lecturers must teach through online learning and apply current teaching strategies using teaching platforms. Learners should learn through the learning platform. Lecturers are trying to re-research to adopt appropriate teaching strategies to help foreign language learners to learn through online learning. (Heydari \& Bagheri, 2012) during the Covic 19 outbreak. Teachers' teaching has moved from onsite to online, learning material moved from printed text to hypertext, and learning media moves from real/ printed media to digital media. Learners' learning strategies have also changed from onsite to online learning strategies in reading course classes. Thus, it is essential to explore the online reading strategies used and their influencing factors in reading academic texts during the Covic 19 pandemic outbreak by foreign language learners.

The research problems of this study are: How do foreign language learners use the online reading strategy in academic reading during the Covid 19 outbreak? Does motivation influence the online reading strategy used by foreign language learners during the Covid 19 outbreak? How does motivation influence online reading strategies by foreign language learners during the Covid 19 outbreak?

The objectives of this study are: To explore the use of online reading strategy in academic reading by foreign language learners during the Covid 19 outbreak; To find out the influence motivation on the use of online reading strategy by foreign language learners during the Covid 19 outbreak; To analyze how motivation influence online reading strategies by foreign language learners during the Covid 19 outbreak.

\section{METHODS}

A mixed-methods research design involves qualitative and quantitative data collection in response to research questions (Creswell JW, 2013) to explore the foreign language learners' online reading strategy and its influential factor. According to Creswell JW (2013), there are three basic mixed methods designs: parallel convergent mixed methods design, mixed methods sequential explanation, and mixed methods sequential exploration, but this study applies only a convergent parallel mixed-method design. This research focuses on analyzing learners' online reading strategies and looking for factors that influence the selection and use of reading learning strategies. 
The study population was 112 English Language Study Program students at State University in Riau Province, Indonesia. Twenty-five students who were studying the Reading III course were selected randomly as the sample. The number of samples, especially for qualitative data, is determined by how much information can be explored (the snowball sampling); the sample size is not a definitive measure and can be defined in advance. (Mudjianto, 2018).

The instruments were adapted from MARS with 35 categories (Mokhtari \& Reichard, 2002) and MARSI-R with 15 categories (Mokhtari et al., 2018), and Online Strategic Reading Button (OSRB) (Huang et al., 2009). Then combine these two types with social and affective reading strategy (Oxford, 1990) assumes that online reading activities also involve social and affective activities. Thus, the instrument of this study consisted of global, problem-solving, support, and socio-affective strategies named Online Academic Reading Strategy (OARS) with four indicators and 42 items. A web-based questionnaire was developed to collect quantitative data about online reading strategies in academic reading by second language learners. The questionnaires were to get information about learners' online reading strategies and following the research objectives. The questionnaires consist of 42 statements, and each report is followed by five numbers, 1,2,3,4 and 5 .

The qualitative data is collected from respondents subjects to research objectives and context (Creswell, 2005). Open-ended questions and in-depth interviews were used to explore (deep exploration) information about learners' online reading strategies. These factors influence the use of learning strategies and the motivation toward online reading strategies. A four-step iterative guide for interview design: settle an epistemological tradition, prepare the interview protocol, conduct the interview, and iterate to reflect before moving (Arsel, 2017) was done to design the interview instrument. By the in-depth interview, information was dug up when the answers of research subjects are still vague, incomplete, off-topic, or non-specific.

The researcher asks various deep questions closely related to the object under study through in-depth interviews and essay questions. In-depth interviews provide much more detailed information than other data collection methods. In-depth interviews accommodate or detect the information needed and reveal as much information as possible according to the study's objective (Arsel, 2017). In-depth interviews using WhatsApp video call and with students to explore reading strategies and factors that influence the selection and use of reading strategies. Interviews were done repeatedly by peer-checking and contrastive analysis for the data validation process. The interview consisted of 10 questions focusing on online reading learning strategies used and the factors influencing reading strategies. When exploring factors affecting online reading strategies for academic reading, learners mentioned motivation, gender, learning facilities, and age factors besides socioeconomic status and individual differences but out of research focus.

\section{Data analysis procedures}

Statistical analysis using SPSS 25 version was used for the validity of the data, and Cronbach's Alpha was used for the reliability of the data. Descriptive statistical analysis by Excell forms was used to identify learners' online reading strategy and the statistical analysis using Pearson Correlation to determine the influence of motivation on foreign language learners' online reading strategy. The procedure of in-depth interviews are as follows; make a plan for the interview, develop the instrument to use, train the interviewer how to collect the data, analyze the data and disseminate the data in the team for data verification and reduction (Boyce \& Neale, 2006). For validity and reliability data, expert checking, back and forth analysis, and triangulation were done. Triangulation is intended to compare and re-check data obtained through different tools and times (Denzin \& Lincoln, 2018). The interview data was carried out through the following procedures:

- Comparing primary data with secondary data.

- Comparing data submitted by respondents in public with what was said in a private place.

- Comparing data submitted by respondents at different times with the same topic.

- Comparing the data obtained with other sources and relevant theories. 
- Experts checking

The data were analyzed soon after being collected. The inductive analysis begins by finding out the themes of the data and the patterns' relationships. Firstly, the data was transcribed verbatim and peer-checking for the validity and reliability data. Thematic analysis was carried out for the data interpretation process. The data obtained from interviews, questionnaires, and essay questions were then analyzed by grouping the data into categories and subcategories. The theme of the interview data was compared with the data from the questionnaire and essay test. Data reduction is carried out first for multiple themes or unrelated data.

\section{FINDINGS AND DISCUSSION}

\section{Validity and Reliability of the Data}

The validity of the quantitative data through the Pearson Product moment found that the value of the $\mathrm{r}$ table with $\mathrm{N} 42$ at significance level 0.05 was 0.344 . The $\mathrm{r}$ counted for all item were higher than 0.344. It means that the questionnaire was valid where $\mathrm{r}$ counted $0.344>\mathrm{r}$ table 0.344 at the significance level 0.05. Forty-one questionnaire items were valid, and one item was revised as presented in figure 1 below.

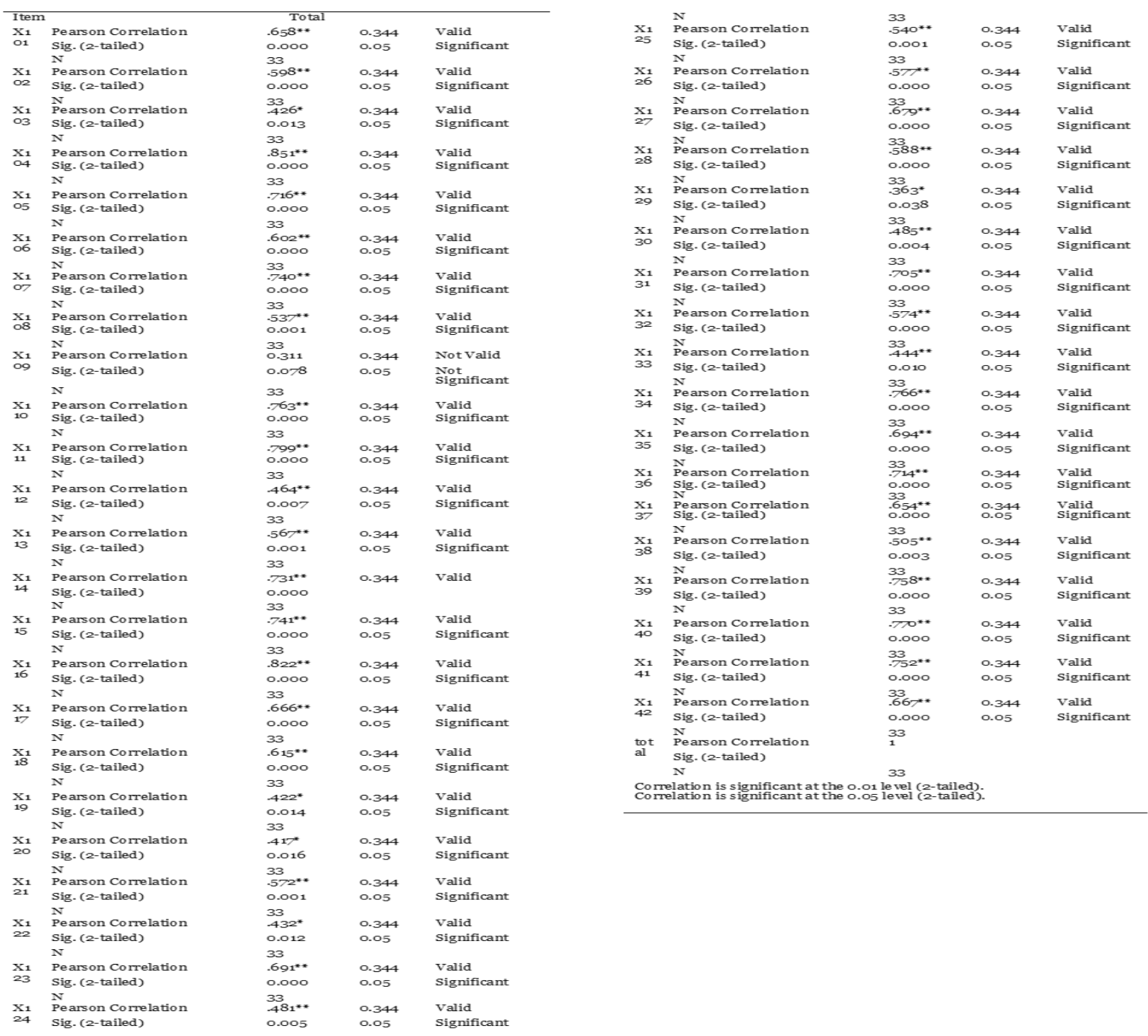

Figure 1. The validity of Instrument Questionnaires of Students OARS 
The reliability data showed that the Cronbach Alfa value was $0.958>0.60$. The questionnaire is reliable when the Cronbach Alfa value > 0.60 (Kadir, 2015). Shortly, the questionnaire for this study is consistent for repeated use, as shown in Figure 2 below.

\begin{tabular}{cr}
\multicolumn{2}{c}{ Table 2 Reliability Testing } \\
\hline \multicolumn{2}{c}{ Reliability Statistics } \\
\hline Cronbach's Alpha & N of Items \\
.958 & \\
\hline
\end{tabular}

Figure 2. Reliability Testing

There were three kinds of data in this study. Quantitative data were obtained through questionnaires and qualitative data through interviews and open-ended questions. Descriptive statistical analysis was applied to answer the research question.

\section{The Use of Online Reading Strategy in Academic Reading by Foreign Language Learners during Covid- 19 Outbreak}

How do foreign language learners use the online reading strategy in academic reading during the Covid 19 outbreak? Foreign language learners use the online reading strategy in academic reading during the Covid 19 outbreak are varied. They used online reading strategies, including global, problem-solving, support, and socio- effective strategy differently. Each strategy is explained in the following.

a. Global strategy

The online reading strategy applied by students during the Covid 19 outbreak was global, as presented in Table 1 below

Tabel 1. Global Strategy

\begin{tabular}{|c|c|c|c|c|c|c|c|c|}
\hline No & Description & 1 & 2 & 3 & 4 & 5 & Total & Related \\
\hline 1 & Have a purpose in mind & 2 & 2 & 11 & 9 & 9 & 120 & 3.636 \\
\hline 2 & Live chat participation with friends & 2 & 5 & 13 & 7 & 5 & 105 & 3.181 \\
\hline 3 & $\begin{array}{l}\text { Live chat participation with a } \\
\text { foreigner }\end{array}$ & 4 & 10 & 10 & 6 & 3 & 93 & 2.818 \\
\hline 4 & $\begin{array}{l}\text { Think about what makes } \\
\text { understanding. }\end{array}$ & 1 & 1 & 9 & 10 & 12 & 130 & 3.929 \\
\hline 5 & $\begin{array}{l}\text { Take an overall view before } \\
\text { reading. }\end{array}$ & 1 & 3 & 15 & 4 & 10 & 118 & 3.575 \\
\hline 6 & Anticipating to the text read & o & 3 & 17 & 7 & 6 & 115 & 3.484 \\
\hline 7 & $\begin{array}{l}\text { Preview essay type and its } \\
\text { organization }\end{array}$ & 2 & 4 & 18 & 4 & 4 & 103 & 3.121 \\
\hline 8 & $\begin{array}{l}\text { Make evaluation to read and do not } \\
\text { read the part of the text. }\end{array}$ & o & 1 & 13 & 12 & 7 & 124 & 3.121 \\
\hline 9 & Read for learning purposes. & 1 & 2 & 17 & 4 & 9 & 117 & 3.545 \\
\hline 10 & Preview graphic, table, and figures & 1 & 3 & 15 & 4 & 10 & 118 & 3.575 \\
\hline
\end{tabular}




\begin{tabular}{|c|c|c|c|c|c|c|c|c|}
\hline 11 & Applying contextual clues. & 1 & 2 & 12 & 13 & 5 & 118 & 3.575 \\
\hline 12 & $\begin{array}{l}\text { Identify keywords using } \\
\text { typographical features. }\end{array}$ & $\mathrm{O}$ & 8 & 9 & 10 & 6 & 113 & 3.424 \\
\hline 13 & Evaluate and analyze critically & 2 & 7 & 13 & 10 & 1 & 100 & 3.030 \\
\hline 14 & Cross check for understanding. & 2 & o & 11 & 14 & 6 & 121 & 3.666 \\
\hline 15 & Guesing through context & 1 & 4 & 10 & 10 & 8 & 119 & 3.606 \\
\hline 16 & Re-check the guessing & $\mathrm{O}$ & 2 & 10 & 15 & 6 & 124 & $3 \cdot 757$ \\
\hline 17 & $\begin{array}{l}\text { Scanning before chosing the } \\
\text { essay. }\end{array}$ & 1 & 6 & 15 & 7 & 4 & 106 & 3.212 \\
\hline 8 & Read pages for fun. & 1 & 3 & 10 & 10 & 9 & 122 & 3.696 \\
\hline & Total Rata-rata & & & & & & & 61.355 \\
\hline & Average & & & & & & & $3 \cdot 41$ \\
\hline
\end{tabular}

The average score for global strategies applied by students was 3.41. It means the implementation of the global strategy in online reading activities was at a medium level. The learners used 18 categories of the global strategy of the online reading strategy. The category "think about what makes understanding," a critical reading activity, was used more than other categories by the learners. This means that critical reading was mostly applied in online reading activities. Meanwhile, the least category applied was " Live chat participation with a foreigner," meaning that the students reading strategy is more interactive and not passive as students were less interested if only as participants.

\section{b. Problem solving strategy}

The second strategy applied by learners in reading online was "problem-solving strategy," as illustrated in table 2:

Table 2. Problem-solving Strategy

\begin{tabular}{|c|c|c|c|c|c|c|c|c|}
\hline No & Categories & 1 & 2 & 3 & 4 & 5 & Total & Average \\
\hline 1 & $\begin{array}{l}\text { Read slowly and carefully to } \\
\text { ensure reading }\end{array}$ & 1 & 2 & 9 & 9 & 12 & 128 & 3.878 \\
\hline 2 & $\begin{array}{l}\text { Get back on tarck when out of } \\
\text { point }\end{array}$ & 3 & 2 & 7 & 11 & 10 & 122 & 3.696 \\
\hline 3 & Adjust my online reading speed & 0 & 5 & 11 & 14 & 3 & 114 & 3.454 \\
\hline 4 & $\begin{array}{l}\text { Pay closer attention when find } \\
\text { difficullty. }\end{array}$ & 2 & 0 & 6 & 13 & 12 & 132 & 4.06 \\
\hline 4 & $\begin{array}{l}\text { Take a time to think what the } \\
\text { text is }\end{array}$ & 1 & 2 & 12 & 13 & 5 & 118 & 3.575 \\
\hline 6 & $\begin{array}{l}\text { Try imagining or visualizing to } \\
\text { remember }\end{array}$ & o & 8 & 10 & 7 & 8 & 114 & 3.454 \\
\hline 7 & $\begin{array}{l}\text { Re-read the text to increase } \\
\text { understanding }\end{array}$ & 1 & 3 & 7 & 10 & 12 & 128 & 3.878 \\
\hline 8 & $\begin{array}{l}\text { Guessing unknown words or } \\
\text { phrases for meaning }\end{array}$ & 1 & 2 & 9 & 13 & 8 & 124 & 3.757 \\
\hline 9 & $\begin{array}{l}\text { Critical evaluation before using } \\
\text { the information }\end{array}$ & 1 & 5 & 11 & 12 & 4 & 112 & $3 \cdot 393$ \\
\hline 10 & Distinguish fact and opinion. & 2 & 4 & 11 & 10 & 6 & 113 & 3.425 \\
\hline 11 & $\begin{array}{l}\text { Look for both sides to cover the } \\
\text { issues. }\end{array}$ & 3 & 3 & 14 & 9 & 4 & 107 & 3.242 \\
\hline & Total & \multicolumn{7}{|c|}{$35 \cdot 756$} \\
\hline & Average & \multicolumn{7}{|c|}{3.250} \\
\hline
\end{tabular}


Learners' problem-solving strategies based on data analysis have 11 categories. Implementing a problem-solving strategy with a range of 1-5 reaches an average value of 3.25 and is medium level. The category "pay closer attention when online text becomes difficult" was mainly applied with an average score of 4.06 (high level), which means students have a high critical reading ability. Meanwhile, the lowest category is " look for both sides to cover the issues when reading hyper-text," with an average value of 3,242 (low level), which means that students' previewing skill is not widely applied.

\section{c. Support Strategy}

The third strategy the students applied when reading online was the support strategy. Support strategy is something that learners used to help them understanding reading online. The support strategies categories are using the online dictionary, taking notes, highlighting important information, using translation tools, using the read tool, etc. The results of the data analysis for the support strategy are in table 3 below.

Tabel 3. Support strategy

\begin{tabular}{|c|c|c|c|c|c|c|c|c|}
\hline No & Categories & 1 & 2 & 3 & 4 & 5 & Total & Average \\
\hline 1 & Note-taking to comprehension & 1 & 3 & 15 & 4 & 10 & 118 & 3.76 \\
\hline 2 & $\begin{array}{l}\text { Switch on a read-aloud tool to help } \\
\text { understand when online text } \\
\text { becomes difficult, }\end{array}$ & 1 & 2 & 9 & 9 & 12 & 128 & 3.88 \\
\hline 3 & $\begin{array}{l}\text { Print out the online text, then } \\
\text { underlines information to help } \\
\text { remember. }\end{array}$ & 3 & 10 & 13 & 2 & 5 & 89 & 3,70 \\
\hline 4 & $\begin{array}{l}\text { Use reference materials (online } \\
\text { dictionary) to help understand }\end{array}$ & 1 & 3 & 8 & 9 & 12 & 127 & 3.84 \\
\hline 5 & Paraphrasing for better understand & o & 9 & 9 & 10 & 5 & 111 & 3.63 \\
\hline 6 & $\begin{array}{l}\text { Back and forth analysis to see the } \\
\text { relationships among ideas. }\end{array}$ & $\mathrm{O}$ & 2 & 16 & 12 & 2 & 110 & $3 \cdot 33$ \\
\hline 7 & $\begin{array}{l}\text { Ask self- questions answer the } \\
\text { online text. }\end{array}$ & 2 & 1 & 13 & 12 & 5 & 116 & 3.52 \\
\hline 8 & $\begin{array}{l}\text { Translate online from English into } \\
\text { a native language. }\end{array}$ & 2 & 3 & 13 & 12 & 3 & 110 & 3.33 \\
\hline 9 & $\begin{array}{l}\text { Link to information in L2 and L1 } \\
\text { using keywords search }\end{array}$ & 0 & 3 & 10 & 10 & 7 & 123 & 3.73 \\
\hline \multicolumn{2}{|c|}{ Total } & \multicolumn{7}{|c|}{29.02} \\
\hline \multicolumn{2}{|c|}{ Average } & \multicolumn{7}{|c|}{3.63} \\
\hline
\end{tabular}

The third online reading strategy used by students was the support strategy. Students used nine categories of support strategy in online reading activities with an average value of 3.62 ( a moderate level). Categories "Switch on the read-aloud tool when online text becomes difficult was mostly used by learners with an average value of 3.88 ( high level). Like the category "Use reference materials (online dictionary) to understand," it reaches an average value of 3.85. Shortly, the Support strategy using internet tools for online reading got the second-highest strategy after global strategy. This suggests the teacher facilitates learners with support strategy in online reading activities. With 
high skills in digital and technology literacy, learners will achieve the scientific knowledge of the 4.0 Era.

\section{d. Socio-affective strategy}

The socio-affective strategy is a strategy that deals with social-emotional enhancement applied in online reading activities, as illustrated in table 4 below.

Tabel 4. Socio Affective Strategi

\begin{tabular}{|c|c|c|c|c|c|c|c|c|}
\hline No & Categories & 1 & 2 & 3 & 4 & 5 & Total & Average \\
\hline 1 & $\begin{array}{l}\text { Ask friends for questions by using } \\
\text { discussion boards during online } \\
\text { reading }\end{array}$ & 3 & 6 & 14 & 7 & 3 & 100 & 3.03 \\
\hline 2 & $\begin{array}{l}\text { Play online English music box while } \\
\text { doing reading tasks }\end{array}$ & 2 & 8 & 6 & 9 & 8 & 112 & 3.39 \\
\hline 3 & $\begin{array}{l}\text { Ask friends to clarify doubts by using } \\
\text { chat rooms during online reading }\end{array}$ & 1 & 3 & 17 & 7 & 5 & 110 & 3.33 \\
\hline 4 & $\begin{array}{l}\text { Link to email for discussion while } \\
\text { doing tasks online task }\end{array}$ & 3 & 10 & 14 & 6 & o & 89 & 2.70 \\
\hline \multicolumn{2}{|c|}{ Total } & & \multicolumn{6}{|c|}{12,452} \\
\hline \multicolumn{2}{|c|}{ Average } & & \multicolumn{6}{|c|}{3.11} \\
\hline
\end{tabular}

The last online reading strategy used was the socio-affective strategy. The learners were using social media when reading took place, and it was categorized as a socio-affective reading strategy. Their social media platform was WhatsApp, Facebook, Instagrams, Twitter, Line, FB messages, LinkedIn, Pitersers, and Wechat than email. On average, the learners mostly use the music box category with a score of 3.93. They also used chat rooms such as WhatsApp, Instagrams, Line, FB messages, KakaoTalk with a score of 3.33. Learners also used WhatsApp, Instagram, Line, KakaoTalk, Wechat groups for discussion with a score of 3.03. They also used online reading by email but at the lowest frequency with a score of 2.69 (low level). Thus, the socio-affective strategies in online reading with an average of 3.11 are at a moderate level strategy.

Shortly, the use of online reading strategies in academic reading by foreign language learners during the Covid 19 outbreak was varied. Four online reading strategies: global, problem-solving, support, and socio-affective strategies, were applied in reading academic text during the Covid 19 outbreak. On average, the second language learners used the global strategy was 3.41 (moderate), the support strategy was 3.63 ( high), the problem-solving strategy was 3.25 (average), and socioaffective was 3.11 (average). Foreign language learners more preferred the support strategy in online academic reading. However, the social interaction was always maintained to run well during Covid 19 outbreak. In general, online reading strategies used by foreign language learner in academic reading during the Covid 19 outbreak was at a moderate level. E-learning strategies were moderately effective in learning foreign languages, and analysis using structural equation modelling showed that e-learning strategies predicted students' online learning outcomes. (Lin et al., 2017).

\section{The Influence of Motivation on the Online Reading Strategy by Foreign Language Learners during the Covid 19 Outbreak}

Motivation significantly influences online reading strategies used by foreign language learners during the Covid 19 outbreak. Motivation influenced the selection and use of online reading strategies. Vocabulary mastery, the language learning environment, student attitudes and beliefs, and learning motivation affected language learning strategies (Yaacob et al., 2018). Motivation plays an essential role in learning reading. The statistical analysis using Pearson Correlation is presented in table 5 below. 
Table 5. The Correlation of Motivation to Online Reading Strategy Correlations

\begin{tabular}{|c|c|c|c|}
\hline & & Motivation & Reading Strgy \\
\hline \multirow[t]{3}{*}{ Motivation } & Pearson Correlation & 1 & $.364^{x}$ \\
\hline & Sig. (2-tailed) & & .037 \\
\hline & $N$ & 33 & 33 \\
\hline \multirow[t]{3}{*}{ Reading Strgy } & Pearson Correlation & $.364^{\star}$ & 1 \\
\hline & Sig. (2-tailed) & .037 & \\
\hline & $\mathrm{N}$ & 33 & 33 \\
\hline
\end{tabular}

There is a positive correlation between motivation and the online reading strategy used. Statistical analysis using SPSS obtained $\mathrm{r}$ value is 0.364 . The significance test result is $0.037<0.05$ means there is a significant correlation between motivation and the online reading strategy used. $\mathrm{N}$ $=33$, at a significance level of 0.05 , the $\mathrm{r}$ table value is 0.344 , and the Pearson correlation value is 0.364 . The value of $r$ counted $0.364>\mathrm{r}$ table 0.344 means a correlation between motivation and the online reading strategy used was positive. The correlation value between $0.20-0.40$ is categorized as low Correlation. At the significance level 0.05 , with $\mathrm{df} \mathrm{N-2}$, the accounted value was 2.176 , and the table value was 2.039. Motivation influenced $13,65 \%$ to the use of online reading strategy. It was found that motivation significantly affects online reading strategies used by foreign language learners during the Covid 19 outbreak. New ecologies of language learning are re-configured due to technological advances and learners' motivation (Lamb et al., 2020). Shortly, motivation influenced the foreign learners' online reading strategies in academic reading during the Covid 19 outbreak, while age and sex had less influence.

\section{Type of Motivation that Influences Online Reading Strategies by Foreign Language Learners during the Covid 19 Outbreak}

The thematic analysis of qualitative data through the triangulation method of the interview data, open-ended questions, and questionnaires interpreted that motivation influenced online reading strategies used with two different purposes: integrative and instrumental motivation, as presented in table 6 below

Tabel 6. Integrative Motivation and Instrumental Motivation

\begin{tabular}{llll}
\hline Description & Themes & $\begin{array}{l}\text { Motivation } \\
\text { Categories }\end{array}$ & $\begin{array}{l}\text { Online Reading } \\
\text { strategies }\end{array}$ \\
\hline $\begin{array}{l}\text { To work abroad } \\
\text { To get a job }\end{array}$ & Job & Instrumental & $\begin{array}{l}\text {-Global } \\
\text {-Support } \\
\text { To be an English } \\
\text { teacher. }\end{array}$ \\
$\begin{array}{l}\text { For job carrier } \\
\text { To work in a foreign } \\
\text { company, not abroad. }\end{array}$ & & & -Socio-affective \\
$\begin{array}{l}\text { To meet different } \\
\text { people. }\end{array}$ & People & & \\
$\begin{array}{l}\text { To have different } \\
\text { friends. }\end{array}$ & Friends & & \\
$\begin{array}{l}\text { To have a lot of } \\
\text { friends. }\end{array}$ & & & \\
$\begin{array}{l}\text { Communicate with } \\
\text { native }\end{array}$ & Communication \\
$\begin{array}{l}\text { To learn the native } \\
\text { culture }\end{array}$ & Native culture & Integrative & \\
& & & -Socio-affective \\
& & & -Support \\
& & &
\end{tabular}




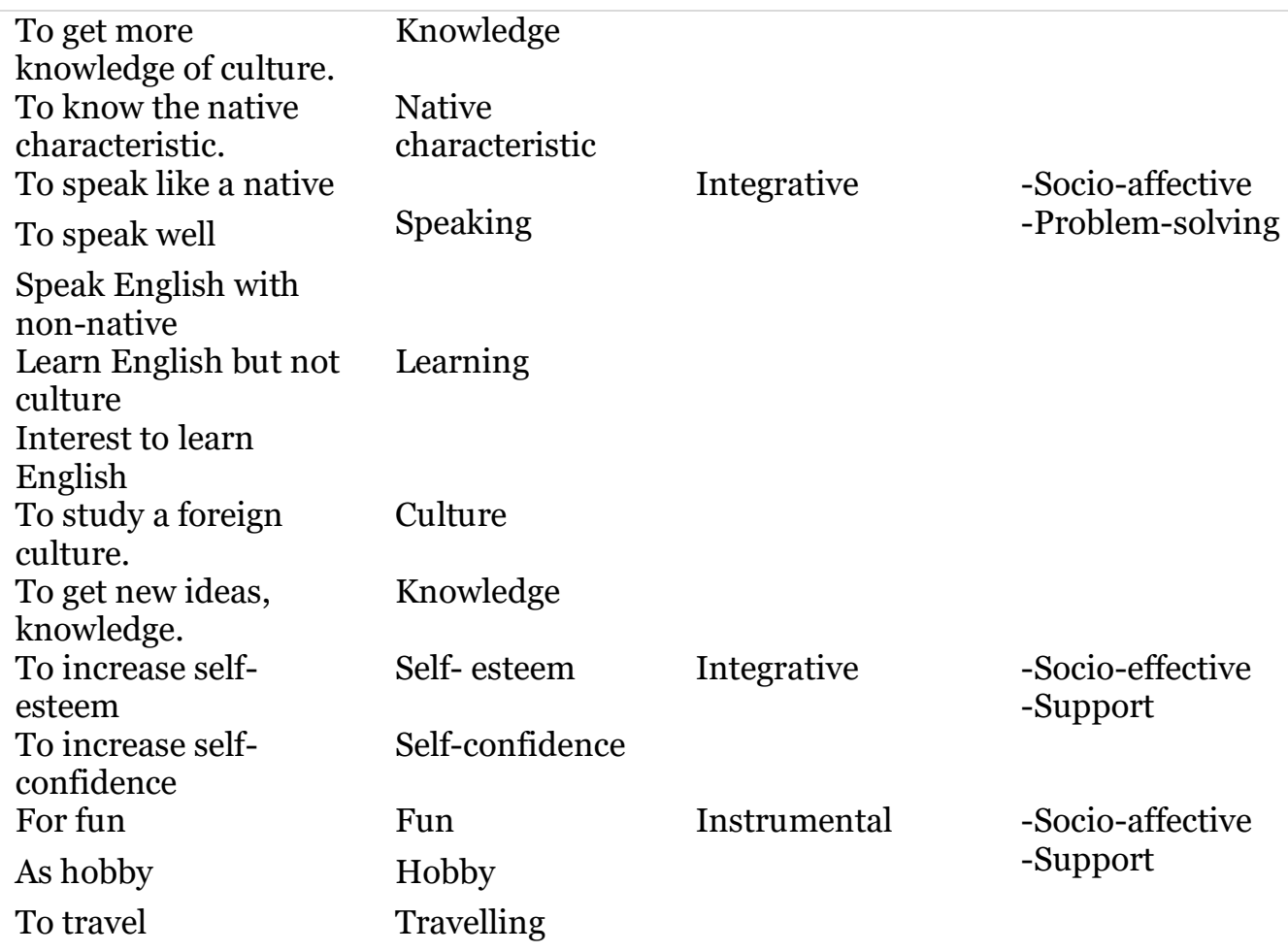

Motivation made a significant contribution to the use of language learning strategies even though ethnicity also had a considerable influence on selecting and implementing language learning strategies (Khamkhien, 2010). Data analysis identified seventeen themes with two categories, namely integrative and instrumental motivation. Instrumental motivation is learning English meant to support specific goals concerning work and other needs. Integrative motivation is learning English to participate in the culture, know the culture, and interact with the language studied (Gardner, 1985). Foreign language learners' motivation influenced online reading strategies used for two purposes, namely integrative and instrumental. Integrative and instrumental motivation influenced their four online reading strategies, e.g., global, problem-solving, support, and socioaffective strategies.

Motivation influences online reading strategies used by foreign language learners during the Covid 19 outbreak for two purposes: instrumental and integrative purposes. The learners with instrumental motivation used global, support, and socio-affective strategies, while the learners with integrative motivation used problem-solving, socio-affective, and support strategies. The foreign language learners' instrumental motivation to learn academic reading is their desire to achieve future goals such as getting a job, meeting people and friends, fun, hobbies, and travelling. On the other hand, their integrative motivation to learn academic reading is to participate in language society and culture for communication and know native culture, knowledge, characteristics, speak, self-esteem, and self-confidence. Integratively motivated learners to learn a new language is to identify with or become part of a new social or cultural group. They want to integrate into the culture of the language they have learned. On the other hand, instrumentally motivated learners want to acquire language to achieve instrumental or practical goals, such as further career, reading technical material, translation. (Gardner, 1985).

\section{CONCLUSION}

During the Covid 19 outbreak in Indonesia, online reading strategies used by the foreign language learners were varied in four different strategies, namely, global strategy, problem-solving strategy, support strategy, and socio-affective strategy. Motivation significantly influenced online reading strategies used by foreign language learners; meanwhile, age and gender factors had 
insignificant influences. This motivation affected foreign language learners' online reading strategies for two purposes: integrated and instrumental motivation. Both motivations affected and controlled the procedure and outcomes of language learning.

The following researchers suggest studying individual differences, socioeconomic status, and other factors on online reading strategies. Further studies on how learners gain knowledge with the appropriate use of reading strategies to enhance them in achieving learning objectives and selfcontrol are also needed. The University provides learners with internet availability and computer technology hardware because learning strategies have changed since Covid 19 hit all aspects of life, including the academic sector. The lecturers also need to create a conducive learning environment through an online teaching approach.

This study has some practical implications. The lecturers encourage foreign language learners' motivation and use appropriate online reading strategies to achieve learning goals but not just focus on achieving learning goals. The lecturers give psychological support to the learners' problems because online reading activities are also affected by internet accessibility, electrical availability, and learners' environmental situation. The lecturer is also required to ensure foreign language learners' internet connection before starting an online reading.

The study's limitations were on the data gained through essay questions and in-depth interviews, which were essential, but it was out of research focus. Individual differences, socioeconomic status were also found and affected foreign language learners' online reading strategies. Unfortunately, these data should be discarded or reduced because of the researcher's capability in terms of time, researcher team, and financial support. Motivation, gender, age, cultural background, attitudes and beliefs, type of task, background learning experiences, socioeconomic status, learner differences affected the strategies used (Kamarul Shukri et al., 2009).

\section{REFERENCES}

Teh, K. S., Embi, M. A., Nik Yusoff, N. M. R., \& Mahamod, Z. (2012). Hubungan Tahap Motivasi Dengan Strategi Pembelajaran Bahasa Arab Dalam Kalangan Pelajar Sekolah Menengah Agama Terengganu. Jurnal Teknologi. https://doi.org/10.11113/jt.v52.137

Alhajri, R., Alhunaiyyan, A. A., \& AlMousa, E. (2017). Understanding the impact of individual differences on learner performance using hypermedia systems. International Journal of Web-Based Learning and Teaching Technologies, 12(1), 1-18. https://doi.org/10.4018/IJWLTT.2017010101

Arsel, Z. (2017). Asking questions with reflexive focus: A tutorial on designing and conducting interviews. Journal of Consumer Research, 44(4), 939-948. https://doi.org/10.1093/jcr/ucxo96

Boyce, C., \& Palena Neale. (2006). Conducting In-Depth Interviews: A Guide for Designing and Conducting In-Depth Interviews for Evaluation Input. In Evaluation (Vol. 2, Issue May). Pathfinder. Co.

Chapelle, C. A., \& Sauro, S. (2017). Introduction to the Handbook of Technology and Second Language Teaching and Learning . The Handbook of Technology and Second Language Teaching and Learning, 1-9. https://doi.org/10.1002/9781118914069.ch1

Creswell, J. (2005). Educational research: Planning, conducting, and evaluating quantitative and qualitative research. Upper Saddle River. Research Design. Qualitative, and Mixed Methods Approaches.

Creswell JW. (2013). Research Design Qualitative, Quantitative, and Mixed Method Approaches by John W. Creswell. SAGE Publications.

Deci, E. L., \& Ryan, R. M. (1985). Intrinsic Motivation and Self-Determination in Human Behavior. SPRINGER SCIENCE+BUSINESS MEDIA. LLC.

Denzin, N. K., \& Lincoln, Y. S. (2018). The SAGE Handbook of Qualitative Research Fifth Edition. In Synthese (Vol. 195, Issue 5). SAGE Publications, Inc. https://doi.org/10.1007/s11229-0171319-X

Emma, M., \& Arina Anis, A. (2020). COVID-19 and communication planning. Malaysian Journal of Communication, 36(1), 1-2. http://ejournal.ukm.my/mjc/article/view/38718/10355

Gardner, R. (1985). Social Psychology and Second Language Learning. Edwar Arnold Publisher. 
Ghanea, M., Pisheh, H. R. Z., \& Ghanea, M. H. (2000). The relationship between motivation and English proficiency among iranian EFL learners. Indian Journal of Applied Linguistics, 26(1), $39-52$.

Huang, H. chou, Chern, C. lan, \& Lin, C. cheng. (2009). EFL learners' use of online reading strategies and comprehension of texts: An exploratory study. Computers and Education. https://doi.org/10.1016/j.compedu.2008.06.003

James, M. A. (2012). An Investigation of Motivation to Transfer Second Language Learning. Modern Language Journal, 96(1), 51-69. https://doi.org/10.1111/j.1540-4781.2012.01281.x

Kadir. (2015). Statistika Terapan (2nd ed.). PT. Raja Grafindo Persada.

Kamarul Shukri, M. T., Mohamed Amin, E., Nik Mohd Rahimi, N. Y., \& Zamri, M. (2009). Strategi Metafizik: Kesinambungan Penerokaan Domain Strategi Utama Pembelajaran Bahasa. GEMA Online Journal of Language Studies.

Karimi, M. N., \& Hosseini Zade, S. S. (2019). Teachers' use of motivational strategies: effects of a motivation-oriented professional development course. Innovation in Language Learning and Teaching. https://doi.org/10.1080/17501229.2017.1422255

Khamkhien, A. (2010). Factors Affecting Language Learning Strategy Reported Usage by Thai and Vietnamese EFL Learners. Electronic Journal of Foreign Language Teaching, 7(1), 66-85.

Kormos, J., \& Csizér, K. (2008). Age-related differences in the motivation of learning English as a foreign language: Attitudes, selves, and motivated learning behavior. Language Learning, 58(2), 327-355.

Lamb, M., Csizér, K., Henry, A., \& Ryan, S. (2020). The palgrave handbook of motivation for language learning. In The Palgrave Handbook of Motivation for Language Learning. https://doi.org/10.1007/978-3-030-28380-3

Lin, C. H., Zhang, Y., \& Zheng, B. (2017). The roles of learning strategies and motivation in online language learning: A structural equation modeling analysis. Computers and Education, 113. https://doi.org/10.1016/j.compedu.2017.05.014

Marboot, K., Roohani, A., \& Mirzaei, A. (2020). Investigating Iranian EFL Students' Metacognitive Online Reading Strategies, Critical Thinking, and their Relationship: A Mixed-Methods Study. Issues in Language Teaching.

Mercer, S., \& Ryan, S. (2016). Stretching the boundaries: Language learning psychology. Palgrave Communications, 2(May). https://doi.org/10.1057/palcomms.2016.31

Mokhtari, K., Dimitrov, D. M., \& Reichard, C. A. (2018). Revising the metacognitive awareness of reading strategies inventory (MARSI) and testing for factorial invariance. Studies in Second Language Learning and Teaching. https://doi.org/10.14746/ssllt.2018.8.2.3

Mokhtari, K., \& Reichard, C. A. (2002). Assessing students' Metacognitive Awareness of Reading Strategies. Journal of Educational Psychology, 94(2), 249-259. https://doi.org/10.1037/0022-0663.94.2.249

Mudjianto, B. (2018). Tipe penelitian ekxplorasi komunikasi:Exploratory reasearc in communication study. Jurnal Studi Komunikasi Dan Media, 2(4), 2407-2415.

Sekuler, A. B., \& Bennett, P. J. (2000). Teaching the brain to see. In Neuron (Vol. 27, Issue 1). https://doi.org/10.1016/So896-6273(00)00024-6

Shen, M. Y. (2013). Toward an understanding of technical university1 EFL learners' academic reading difficulties, strategies, and needs. Electronic Journal of Foreign Language Teaching, 10(1), 70-79.

Tan, K. H., Woods, P., Azman, H., Abdullah, I. H., Hashim, R. S., Rahim, H. A., Idrus, M. M., Said, N. E. M., Lew, R., \& Kosem, I. (2020). COVID-19 insights and linguistic methods. 3L: Language, Linguistics, Literature, 26(2), 1-23. https://doi.org/10.17576/3L-2020-2602-01

Yaacob, A., Shapii, A. bt., Saad, A. A., Al-Rahmi, W. M., Al-Dhelea, Y. M., Yahaya, N., \& Al-Maatouk, Q. (2018). Factors affecting students' learning strategies at school Aizan. International Journal of Engineering and Technology(UAE), 7(4), 3697-3701. https://doi.org/10.14419/ijet.v7i4.16885 